\title{
The Tie That Binds: Exploring Community College Curriculum Design
}

Bobbi Gentry, Bridgewater College

Christopher Lawrence, Middle Georgia State University

Erin Richards, Cascadia Community College

ABSTRACT More students are beginning their college careers at community colleges before completing degrees at four-year institutions. As enrollments swell at these two-year institutions, issues surrounding transfer and articulation agreements are increasingly important, and two- and four-year institutions must work together on the recruitment, retention, and transition of political science majors. Central to this collaboration is the curriculum. Building on conclusions from the 2011 Leadership Collaborative Core Curriculum and General Education track regarding a common curriculum in the discipline, this article examines the political science curriculum using data from 47 two-year colleges with separate political science departments. We examined similarities and differences among these programs and found sufficient commonality in curriculum to allow students to transfer credits to four-year institutions. The article also offers community colleges an indication of common curricular features and informs the wider profession about community college curriculum design.

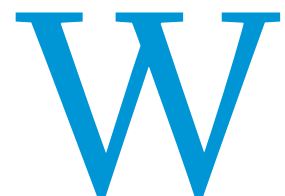

hat do we know about our curriculum within the political science discipline? Since the publication of the influential Wahlke Report (1991), political scientists have considered the extent to which four-year political science majors in the United States have met its recommendations. However, similar attention has not been given to the political science discipline at two-year colleges.

In our experience as department administrators, we often face situations in which students have taken courses at other institutions and it is difficult to apply the coursework to their political science degree programs. This can lead to students failing to progress at the recommended rate, accumulating excess credit hours, and repeating similar course material. This can result

Bobbi Gentry is assistant professor of history and political science at Bridgewater College. She can be reached at bgentry@bridgewater.edu.

Christopher Lawrence is assistant professor and assistant chair of the history and political science department at Middle Georgia State University. He can be reached at christopher.lawrence@mga.edu.

Erin Richards is associate professor at Cascadia Community College. She can be reached at erichards@cascadia.edu. in students being "off track" on their recommended degree plans because they must fulfill prerequisites before moving on to more specialized coursework.

Accordingly, this research focuses on the curriculum design at community colleges with three major purposes: (1) provide knowledge about the curriculum offered at community colleges, (2) evaluate course offerings that may overlap with four-year institutions, and (3) consider how two- ${ }^{-1}$ and four-year institutions can advance the discipline's goals of undergraduate education through deeper collaboration. As a project involving faculty at twoand four-year institutions, we hope this research better informs our audience about how curriculum is shaped and how we can better understand our shared students.

\section{APPLYING RESEARCH ON THE CORE TO COMMUNITY COLLEGES}

Curriculum-design questions are not new to our field. We define "curriculum design" as the set of required courses and electives available to students in a political science program. The Association of American Colleges and Universities (AACU) produced a critique of undergraduate curricula in "Liberal Learning and the 
Arts and Sciences Major." The heart of their criticism was that faculties create specialized courses instead of offering valuable introductory courses that explain how to engage in inquiry within their discipline. The AACU subsequently asked disciplinary societies to evaluate how their disciplines accounted for teaching and learning. Within political science, the product of that initiative was the Wahlke Report to the American Political Science Association (APSA), which proposed recommendations to address the criticism that "political science is too diversely conceptualized, organized, and taught" (Wahlke 1991, 50). The Wahlke Report set forth three major curricular standards for bachelor's programs in the field: an introductory course, a sequential program of courses, and a capstone course.

Accordingly, Breuning, Parker, and Ishiyama (2001) emphasized a structured curriculum that emphasizes knowledge and skills. Their suggestion of a structured curriculum would be not prepared for the expectations of four-year programs when they do transfer.

\section{BACKGROUND AND PURPOSE OF COMMUNITY COLLEGES}

Kane and Rouse (1999) indicated that the scope of community colleges expanded to encompass three major missions: (1) offer a terminal degree in a subject area, (2) provide the first two years of a four-year curriculum in preparation for transfer to a four-year institution, and (3) train students in technical or vocational degrees. Because the purpose of community colleges is to provide greater access to higher education, they typically offer open enrollments and have lower tuition rates (Kane and Rouse 1999). Community colleges and other two-year institutions remain more affordable; according to the College Board (2011), the average in-state tuition for public two-year colleges was between one third and one half of the tuition for public

\section{The Wahlke Report set forth three major curricular standards for bachelor's programs in the field: an introductory course, a sequential program of courses, and a capstone course.}

problematic at community colleges, which typically offer only introductory courses with additional classes reflecting faculty interests. Most community college students take political science courses to meet general education requirements as part of another program rather than as part of a structured study of political science. Four-year institutions also typically include the development of qualitative and quantitative skills found in research-methods courses (Breuning, Parker, and Ishiyama 2001). However, two-year institutions typically do not emphasize developing these skills in their introductory social science courses.

Similarly, Ishiyama, Breuning, and Lopez (2006) discussed the APSA's adoption of the Wahlke Report. However, despite greater attention to the structure of the political science major and an increased focus on demonstrable student-learning outcomes (Ishiyama 2005), many current programs do not follow the report's recommendations. These recommendations include an introductory course on American government taught from a comparative perspective, a research-methods course, and a capstone course. Of the 193 undergraduate programs studied, only $18 \%$ included all three of these components (Ishiyama, Breuning, and Lopez 2006). Their recommendation to improve the undergraduate curriculum by including interested constituencies and creating "institutional forums to sustain such efforts" can be applied to community colleges (ibid., 664).

Within the two-year-college sector, it is likely that conformance with the Wahlke Report recommendations is even lower, for various reasons. Because an associate's degree in political science typically is considered to be a transfer-oriented program, the scope for including classes unlikely to transfer to four-year colleges is limited. Accordingly, offerings are likely to be limited to introductory courses such as American government and those in other subfields. Even if methods and capstone courses were offered, it is unclear whether four-year programs would accept them for transfer credit because they typically are offered at the junior or senior level. However, the lack of methods training in particular may mean that two-year-college students are four-year colleges. Although tuition rates continue to rise, the rate of growth has been slower in the two-year sector than in the four-year sector (i.e., $3.8 \%$ and 5.6\% annually, on average, over inflation, respectively).

Due to the economic recession and families facing financial difficulties, as well as a large pool of veterans with educational benefits, enrollment has surged by $21.7 \%$ since 2007 , resulting in more students attending community college than in previous years. In 2011, community colleges enrolled more than 8 million students, including both full- and part-time students (Mullin and Phillippe 2011).

With the rising cost of higher education, many students choose to begin their four-year degrees at community colleges. Recent research suggests that almost half of all students who completed bachelor's degrees during the 2013-2014 academic year had previously completed coursework at a two-year institution; in several states, including California and Texas, more than $60 \%$ of graduates had done so (National Student Clearinghouse Research Center 2015). Thus, transferability of courses and articulation between two- and four-year institutions has become increasingly important. Students want to know that the classes they take at a community college will transfer to a four-year institution and that they will not need to repeat them. These concerns have led to legislative action and policy changes, including requirements that two- and four-year colleges adopt similar course numbers, common core curriculum requirements, and articulation agreements that grant clear pathways for students to retain credits when they transfer to four-year institutions. Examples of such legislation include California's Senate Bill 1440 (California Community Colleges Chancellor's Office \& California State University 2011), the Texas Common Course Numbering System, and the University System of Georgia (USG) statewide core curriculum.

Transferability can no longer be ignored by political scientists. The study of curriculum design at community colleges provides clarity on what is offered across associate-degree programs and illuminates opportunities for additional course development and transferability among institutions. Faculty and institutions can 
benefit from a clearer articulation of community-college curricula. Community college faculties benefit from a better understanding of faculty expectations at four-year schools in lower-level courses by offering classes at a similar level of rigor to be accepted for transfer credit. Four-year-college colleagues can benefit from knowing what is offered by community colleges as they create " $2+2$ " articulation plans and encounter an increasing number of transfer students. They can respond to policy-maker demands for "reverse transfer" as part of the efforts to increase associate's degree completion rates.

\section{WORKING TOGETHER: COMMON INTERESTS OF TWO- AND FOUR-YEAR FACULTY}

Many students complete core courses in political science at community colleges, including an introduction to American government, state and local government, comparative politics, and/or international relations. Some community colleges with more extensive curricula offer courses on political theory and introduction to politics, as well as specialized courses such as Mexican-American politics, women and politics, and the presidency. However, these specialized courses often reflect interests of the faculty and may not be offered consistently due to faculty turnover.

From a public-policy perspective, a deeper understanding of a typical political science curriculum can inform the actions of policy makers to increase efficiency and transferability between two- and four-year systems. In our society, higher education is increasingly held accountable under a more "business-oriented" model; if we bill students by credit hour, then higher education must account for the services it provides (Credit Hour Advisory Council 2012). As higher education comes under greater political and public scrutiny, political scientists and educators must
Two-year college advisors often are generalists who may be well versed in general-education requirements and degree plans at their own institution. It is uncommon for them to be trained to keep students on track for transfer to particular programs at other institutions. Given the small number of courses in the discipline offered at two-year schools, students may not seek out political science faculty for advice on which courses to take or guidance on which four-year schools are likely to accept transfer credit or offer a major that fits their interests. Although students should be proactive in learning about potential transfer destinations and become familiar with degree requirements, in practice (particularly among first-generation students disproportionately likely to attend two-year schools) they may not do so. As a result, two-year college faculty will need to be proactive in the advising process for " $2+2$ " programs to be effective.

For four-year colleges, formal " $2+2$ " plans are particularly helpful to political science programs seeking to recruit students. They offer clear information for students who are interested in obtaining a bachelor's degree in the discipline. By adopting a " $2+2$ " plan, four-year institutions can indicate specific courses recommended before students transfer and provide guidance on which courses they should take each term. Because many nationwide four-year institutions have eight-semester degree plans, the plans can explain which courses should be taken at a community college and which at the transfer institution. To this end, a deeper relationship between political science faculties at two- and fouryear institutions is necessary to better serve our shared students. We suggest that chairs and faculty take an active role in starting and fostering a relationship among programs.

However, any relationship involving transfer credit should be established in an articulation agreement that clearly denotes which classes will transfer to the four-year institution. This agreement

\section{Although students should be proactive in learning about potential transfer destinations and become familiar with degree requirements, in practice (particularly among first-generation students disproportionately likely to attend two-year schools) they may not do so. As a result, two-year college faculty will need to be proactive in the advising process for " $2+2$ " programs to be effective.}

reflect more carefully on curriculum design to ensure that our input is considered as part of this process of change. Exploring what we teach can identify a core curriculum within political science.

\section{"2+2" ADVISING FOR TRANSFER SUCCESS}

An important variation among institutions that will affect the viability of smooth transfers from two- to four-year programs is the advising model. Whereas four-year institutions have various approaches to advising (including substantial variation in whether and at what point students are assigned faculty advisors rather than relying on nonacademic professional advisors or an advising center), most two-year institutions do not match students with advisors who are well versed in their particular field of study. These advisors often are professional, nonacademic advisors or faculty in disciplines or fields other than those being pursued by students. can be built on an existing general-education articulation agreement (e.g., plans that grant automatic admission and full transfer of credit in the lower division to students who have completed an associate's degree, or plans that map two-year-college courses to four-year-college equivalents) or be created anew. Ideally, to protect students in the pipeline, transfer articulation should be defined in a memorandum of understanding between the twoand four-year institutions. Typically, this would be concluded by the academic affairs offices of both institutions in collaboration with the affected departments and the admissions office of the four-year institution.

\section{METHODS}

To base these curricular decisions in data, we examined the political science curriculum across US community colleges. We drew the sample for our study from the APSA departmental directory of those community colleges with separate political 
science departments. ${ }^{2}$ All 112 community colleges ${ }^{3}$ were investigated; however, not all departments offered an associate's program in political science. 4 Of the 112 colleges investigated, 5 65 lacked a political science degree. Of those remaining, $47 \mathrm{had}$ a degree or emphasis in political science. To ensure a more accurate comparison of curriculum design, we limited our study to those colleges with a degree in political science or government. The primary source for information was the most recent college catalog. When information was unavailable or unclear, we directly contacted the department chair or registrar for clarification.

\section{FINDINGS}

Several of the community-college websites clearly identified transfer-oriented programs of study, presumably because providing the first two years of a four-year education is their primary function.
(28\%) required an international-relations or global-issues course, and 11 programs (23\%) required a comparative-politics course. Although some schools had other requirements, few had requirements beyond these three courses. Introduction to politics or introduction to political science was required in only five programs (11\%). Political theory was required in seven programs $(15 \%)$. One program specifically identified American political theory as a requirement.

\section{DISCUSSION}

We identified two key findings from our research. First, there is a common core in political science at community colleges, dominated by American politics. This result is consistent with the findings of Gentry and Lawrence (2011) on four-year curriculum design. The second major finding is that many institutions do not offer an

\section{As a model, we suggest that the USG core curriculum and common course-numbering system may be effective to ensure transferability without imposing a burden on institutions on both sides of the transfer process or forcing adoption of a particular curriculum structure.}

Even if a community college did not offer a degree in political science, it identified the ability to transfer political science credits as part of a general-education curriculum.

Those political science departments without a degree in either political science or government seemed to contribute to the larger general-education curriculum. Many community colleges had programs in applied areas such as criminal justice, administration of justice, and paralegal training or a general social science degree. Political science courses often were identified as fulfilling general degree requirements for social science coursework; many institutions required at least six hours of social science credit to earn an Associate of Arts (AA). The most common courses offered at schools without an AA degree in political science were introduction to political science (i.e., an overview of the theories, institutions, and major subfields of the discipline), American government, state and local government, introduction to international relations, introduction to comparative government, and internship courses. At some institutions, particularly in Texas, students are required by law to complete a course in American politics and/or state and local government.

Other courses offered at non-degree-granting schools include political philosophy, area studies focusing on a particular region of the globe, and domestic or current issues. Some programs specifically offer courses in public administration or focus on the courts at schools that offer technical certifications in criminal justice. These common course offerings among the nondegree-granting institutions provide evidence of what may be considered the core among political science. Most community colleges include political science courses as part of their generaleducation requirements, mirroring the general-education requirements at four-year institutions.

As shown in figure 1, of the 112 community colleges with separate political science departments, only 47 specifically offered an associate's degree in political science. Of those programs, three courses from three subfields seem to be the core of community-college degrees in political science: 35 programs (74\%) required an American-government course, 13 programs associate's degree in political science but offer concentrations in political science within a general-education transfer degree. This is not unique to political science, however, because most community colleges do not offer terminal AA degrees in non-workforce fields. The transfer emphasis was reinforced by descriptions of programs that emphasize the ability to transfer political science courses to other institutions. Other programs with political science departments had more applied associate's degrees, such as criminal law and paralegal certification. The lack of terminal associate's degrees in political science also may result from low staffing at community colleges, most of which have a significantly smaller student population than four-year institutions and, typically, smaller political science faculties. This means that the faculty may not be able to cover the breadth of the first two years of a political science degree that a larger faculty at a four-year college or university could provide.

Requirements common in bachelor's-degree programs that include methods coursework, a senior thesis or project, internships, and advanced courses in subject areas are rare at community colleges. Instead, these institutions focus on lower-division classes that fulfill general-education requirements or that are likely

\section{Figure 1}

Required Courses at Two-Year Institutions

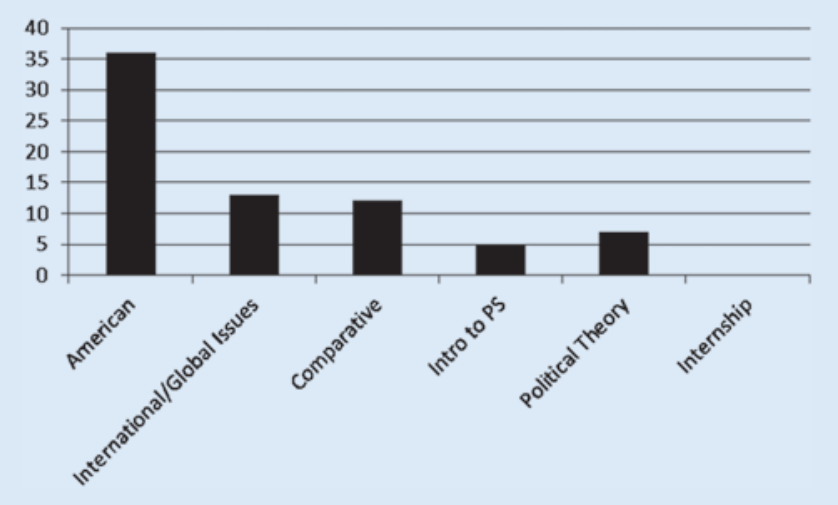


to be accepted for transfer credit in four-year programs. However, some community-college programs offer special-topics courses within at least one major subfield, typically American politics.

When creating articulation agreements between two- and four-year institutions, courses that easily could transfer include introductory courses in American politics, international relations, comparative politics, and political theory. As part of the process, four-year programs should reassess course-sequencing decisions that disadvantage transfer students. As Ishiyama and Hartlaub $(2003,83)$ suggested, sequencing and conscious linking between classes to create a coherent, whole major are extremely important for student learning.

As a model, we suggest that the USG core curriculum and common course-numbering system may be effective to ensure transferability without imposing a burden on institutions on both sides of the transfer process or forcing adoption of a particular curriculum structure. Within the 30 institutions of the USG, a common framework specifies the logical progression through introductory coursework in political science. POLS 1101, Introduction to American Government, is required of all degree-seeking students and typically is taken during the first year; it also is a prerequisite for 2000-level political science coursework. Common courses at the sophomore level-introduction to political science, comparative politics, state and local government, global issues, domestic issues, and public administration-share common course numbers and similar course descriptions, enabling relatively easy transfer among schools that range from predominantly two-year colleges to nationally ranked research universities. The centralized nature of the USG makes this structure easier to impose, and it could be a model for other states and regions as well. ${ }^{6}$ However, even the USG structure does not impose much sequencing beyond requiring an American government class before any other coursework. Given the potential coordination problems involved in implementing a common numbering system, a less sweeping alternative may be for institutions to publicly post or contribute to a shared public database that would record course-articulation decisions made when accepting transfer credit. The database would enable students (or their advisors) who plan to transfer to another college to determine which courses are being accepted for transfer credit by the receiving institution and the specific credits that are likely to be awarded for them. ${ }^{7}$

We believe this research can be extended in several ways. First, a deeper examination of the relationship between faculty headcount and the breadth of course offerings would be valuable: Does having more political science faculty lead to a greater diversity of course offerings? Second, examining the sequencing of courses in political science programs at two-year institutions could greatly improve our knowledge of student learning at community colleges. Third, examining how two-year institutions recruit, retain, and recommend transferring students could determine why there are fewer students in political science at community colleges (Bennett and Bennett 2001).

Fourth, the presence of American politics within the core curriculum may reflect the hegemony of that field within the discipline. We can theorize that many programs have faculty who specialize in American politics or that another federal or state requirement identifies American politics as a necessary course. This question is worthy of further examination.

This research expands our knowledge of community-college curriculum design and is beneficial to both community colleges and four-year colleges and universities. Given that communitycollege curricula are largely driven by transfer requirements, exploring their curriculum design provides a clearer picture of what is meant by core within the discipline as a whole. Identifying the core of what we teach our students also can help us to be more reflective in training future professors.

As we continue to examine the core of the political science curriculum, two- and four-year institutions can work together more frequently and more efficiently to create a better experience for undergraduate political science students. Our greater goal within the discipline is not only to educate future professors but also to provide background knowledge and skills necessary to be successful in the workplace and as citizens of a democracy. As a discipline, we need a more comprehensive discussion about how we can support all faculty in political science and how curricula among institutions can be articulated and transferred.

\section{NOTES}

1. We use the terms "two-year college" and "community college" interchangeably. However, the existence of associate's-granting open-access institutions with bachelor's programs and selective, lower-division-only institutions that do not identify as community colleges make this terminology somewhat problematic.

2. Admittedly, by choosing only those colleges with separate political science departments, we excluded many two-year and community colleges. However, we believe that those with separate departments are better equipped to coordinate their curricula with transfer institutions. Also, by limiting our dataset to departments in the APSA departmental directory, we may have inadvertently perpetuated the organization's historical failure to give sufficient attention to the structure of two-year colleges-which often are organized using nondepartmental models-as well as ignoring institutions that do not appear in the database for other reasons.

3. We focused on separate rather than combined departments to allow for a more specific view of the curriculum within community colleges. As Ishiyama $(2005,73)$ noted, combined departments often are less structured than political science programs. Therefore, finding a common core in the curriculum developed by political scientists is sharpened by studying separate programs.

4. Some of the listings included a community-college system, which were not included in the final analysis because some community colleges in the system offered political science and others did not.

5. Based on the American Association of Community Colleges directory, the 112 community colleges considered include 22 from the Central region, 5 from the Northern region, 39 from the Pacific region, 20 from the Southern region, and 26 from the Western region.

6. A similar approach is used by the Texas Core Course Numbering System, despite including universities and colleges governed by myriad different bodies. This suggests that a single statewide board of regents is not necessary to implement a course-articulation system based on shared numbering. Notably, both systems allow local deviations from the standard numbering as long as comparable courses are treated as equivalent when students transfer credit.

7. An example of such a database at the institutional level from Middle Georgia State University is available at https://astro.mga.edu/pls/COMB/zwsktrna.P find_location.

\section{REFERENCES}

Bennett, Stephen Earl and Linda L. M. Bennett. 2001. "What Political Scientists Should Know about the Survey of First-Year Students in 200o." PS: Political Science \& Politics 34 (2): 295-9.

Breuning, Marijke, Paul Parker, and John T. Ishiyama. 2001. "The Last Laugh: Skill Building through a Liberal Arts Political Science Curriculum.” PS: Political Science \& Politics 34 (3): 657-61.

California Community Colleges Chancellor's Office \& California State University 2011. "SB 1440: Associate Degrees for Transfer." Available at www.sb1440.org.

College Board. 2011. "Trends in College Pricing." Available at http://trends. collegeboard.org/downloads/College_Pricing_2011.pdf.

Credit Hour Advisory Council. 2012. "An Advisory by the Arts Accrediting Association on Federal Definition of the Credit Hour." Available at http://nasm.arts-accredit.org/site/docs/Federal\%2oAdvisories/Credit_Hour Advisory_2012Aug.pdf. 
Gentry, Bobbi G. and Christopher N. Lawrence. 2011. "What's Core in the Political Science Curriculum?" Presented at the 2011 APSA Teaching and Learning Conference, Albuquerque, NM.

Ishiyama, John. 2005. "Examining the Impact of the Wahlke Report: Surveying the Structure of the Political Science Curricula at Liberal Arts and Sciences Colleges and Universities in the Midwest." PS: Political Science \& Politics 38 (1): 71-5.

Ishiyama, John, Marijke Breuning, and Linda Lopez. 2006. "A Century of Continuity and (Little) Change in the Undergraduate Political Science Curriculum." American Political Science Review 100 (4): 659-65

Ishiyama, John and Stephen Hartlaub. 2003. "Sequential or Flexible? The Impact of Differently Structured Political Science Majors on the Development of Student Reasoning." PS: Political Science \& Politics 36 (1): 83-6.
Kane, Thomas J. and Cecilia Elena Rouse. 1999. "The Community College: Educating Students at the Margin between College and Work." Journal of Economic Perspectives 13 (1): 63-84.

Mullin, Christopher and Kent Phillippe. 2011. "Fall 2011: Estimated Headcount Enrollment and Pell Grant Trends." American Association of Community Colleges. Available at http://aacc.nche.edu/Publications/Reports/Documents/ Headcount_Enrollment.pdf.

National Student Clearinghouse Research Center. 2015. "Snapshot Report: Contribution of Two-Year Institutions to Four-Year Completions." Available at http://nscresearchcenter.org/snapshotreport-twoyearcontributionfouryear completions17.

Wahlke, John C. 1991. "Liberal Learning and the Political Science Major: A Report to the Profession." PS: Political Science \& Politics 24 (1): 48-6o. 